\title{
Antepartal insulin-like growth factor 1 and insulin-like growth factor binding protein 2 concentrations are indicative of ketosis in dairy cows
}

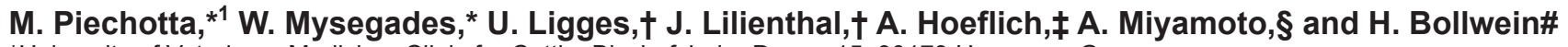 \\ *University of Veterinary Medicine, Clinic for Cattle, Bischofsholer Damm 15, 30173 Hannover, Germany \\ †Department of Statistics, TU Dortmund University, Vogelpothsweg 87, 44221 Dortmund, Germany \\ łLeibniz Institute for Farm Animal Biology, Mouse Genetics, Wilhelm-Stahl-Allee 2, 18196 Dummerstorf, Germany \\ §Obihiro University of Agriculture and Veterinary Medicine, Obihiro, 080-8555 Hokkaido, Japan \\ \#Clinic of Reproductive Medicine, Vetsuisse-Faculty University of Zurich, Winterthurerstr. 260, CH-8057 Zürich, Switzerland
}

\section{ABSTRACT}

A study involving a small number of cows found that the concentrations of insulin-like growth hormone 1 (IGF1) may be a useful predictor of metabolic disease. Further, IGF1 may provide also a pathophysiological link to metabolic diseases such as ketosis. The objective of the current study was to test whether the low antepartal total IGF1 or IGF1 binding protein (IGFBP) concentrations might predict ketosis under field conditions. Clinical examinations and blood sampling were performed antepartum (262-270 d after artificial insemination) on 377 pluriparous pregnant Holstein Friesian cows. The presence of postpartum diseases were recorded (ketosis, fatty liver, displacement of the abomasum, hypocalcemia, mastitis, retention of fetal membranes, and clinical metritis or endometritis), and the concentrations of IGF1, IGFBP2, IGFBP3, and nonesterified fatty acids were measured. Cows with postpartum clinical ketosis had lower IGF1 concentrations antepartum than healthy cows. The sensitivity of antepartal IGF1 as a marker for postpartum ketosis was 0.87 , and the specificity was 0.43 ; a positive predictive value of 0.91 and a negative predictive value of 0.35 were calculated. The cows with ketosis and retained fetal membranes had lower IGFBP2 concentrations compared with the healthy cows. It can be speculated that lower IGF1 production in the liver during late pregnancy may increase growth hormone secretions and lipolysis, thereby increasing the risk of ketosis. Lower IGFBP2 concentrations may reflect the suppression of IGFBP2 levels through higher growth hormone secretion. In conclusion, compared with nonesterified fatty acids as a predictive parameter, IGF1 and IGFBP2 may represent earlier biomarkers of inadequate metabolic adaptation to the high energy demand required postpartum.

Received September 22, 2014.

Accepted January 7, 2015.

${ }^{1}$ Corresponding author: marion.piechotta@tiho-hannover.de
Key words: dairy cow, transition period, insulin-like growth factor 1 , insulin-like growth factor binding protein 2 , ketosis

\section{INTRODUCTION}

The growth hormone (GH)-IGF axis is an important endocrine control center for metabolic adaptation in dairy cows. Studies have indicated that IGF1 may be useful as a predictive marker for postpartum (pp) production diseases (Piechotta et al., 2012) or for successful early ovulation pp (Kawashima et al., 2007). Moreover, from in vitro studies, IGF1 is known to be an important signal for gluconeogenesis (Wang et al., 2012). Therefore, a physiological association between IGF1 and particularly metabolic diseases, such as ketosis, is likely, but the exact mechanisms between the somatotropic axis and the pathogenesis of ketosis are not well studied. Studies have attempted to influence the GH-IGF1 axis by administering bST antepartum (ap). Although ap bST administration did not affect the incidence of hyperketonemia, DMI, or clinical ketosis (Gohary et al., 2014), a clear association between low IGF1 concentrations and metabolic production diseases was evident (Piechotta et al., 2012). Cows that were classified based on low versus high IGF1 levels revealed no differences in the hepatic GH receptor mRNA expression (Piechotta et al., 2013, 2014), which might explain why bST administration did not have an effect on the incidence of ketosis. However, from these studies, it was not clear which factors might be responsible for the association between low total IGF1 levels and the incidence of metabolic diseases. Moreover, the number of cattle used in the study was low, and only IGF1 was measured (Piechotta et al., 2012). However, IGF1 is bound to 6 different high-affinity IGF binding proteins (IGFBP) that determine the half-life of IGF1 and its delivery through the endothelium to the target cells. The IGFBP concentration might be one factor for different total IGF1 concentrations. Therefore, the concentrations of the 2 most abundant IGFBP (IGFBP2 
and IGFBP3) were determined in the present study with a greater number of animals under field conditions to clarify whether ap total IGF1 or IGFBP concentrations might predict the risk of ketosis or other pp production diseases.

\section{MATERIALS AND METHODS}

\section{Animals}

In one large-scale dairy farm $(\sim 1,300$ cows $)$ in eastern Germany (Göritz), 377 pluriparous Holstein Friesian cows in late pregnancy [second to fourth lactation; 305 -d milk yield $=11,200 \pm 97 \mathrm{~kg}($ mean \pm SEM $)]$ were examined and blood samples were obtained. The experimental procedure was approved by the German legislation responsible for animal welfare [Landesamt für Umwelt, Gesundheit und Verbraucherschutz, Abteilung Verbraucherschutz in Frankfurt (Oder); 23-2347-A19-3-2010]. The cows were housed during all seasons in a freestall barn with rubber mats and were fed automatically by a band-conveyor system twice daily with a TMR depending on the lactation period (Tables 1 and 2). The cows were provided with a mineral supply (Deutsche Vilomix Tierernährung GmbH, Neuenkirchen-Vörden, Germany) and they had free access to water. The cows were kept in groups depending on the lactation interval [early (50 d pp), mid, late, and dried-off]. The cows were dried-off approximately $6 \mathrm{wk}$ before the expected calving date. Approximately $10 \mathrm{~d}$ before calving, the cows were placed in a freestall barn with straw bedding in which the cows were monitored for signs of birth every $2 \mathrm{~h}$ by the farm staff. The cows were milked 3 times daily, and the milk yields were recorded once a month by the routine control office (Landeskontrollverband Brandenburg, Brandenburg, Germany).

\section{Monitoring of Health Status and Blood Sampling}

The cows were monitored daily by the farm staff via observing the feed intake ap and pp and recording milk yield, milk character, and the udder after calving. If the cows showed a reduction in either feed intake or milk yield, a farm veterinarian was summoned and the cows were diagnosed and treated. Moreover, the cows were examined clinically by a study veterinarian once ap between 262 and $270 \mathrm{~d}$ after AI and 2 times pp at 3 (16-21 d pp) and 4 wk (22-28 d pp) after calving. At each examination, behavior, posture, body temperature, and BCS were recorded (Edmonson et al., 1989). Additionally, the milk yield during the previous lactation was documented. A gynecological examination was performed to assess the occurrence
Table 1. Ingredients of the TMR fed with regard to the different lactation periods

\begin{tabular}{|c|c|c|c|}
\hline \multirow[b]{2}{*}{ Item (kg of DM) } & \multicolumn{2}{|c|}{ Dry-off ration } & \multirow{2}{*}{$\begin{array}{c}\begin{array}{c}\text { Fresh cow } \\
\text { ration }\end{array} \\
>\mathrm{d} 1 \\
\text { postpartum }\end{array}$} \\
\hline & $\begin{array}{c}\text { wk 6-2 } \\
\text { antepartum }\end{array}$ & $\begin{array}{c}\text { wk } 2-0 \\
\text { antepartum }\end{array}$ & \\
\hline Grass silage & 10.4 & 2.4 & 5.2 \\
\hline Corn silage & 1.3 & 6.6 & 8.1 \\
\hline Sugar beet pulp & - & - & 3.6 \\
\hline Rye straw & 0.3 & - & - \\
\hline Wheat & 0.4 & - & 0.6 \\
\hline Straw & 2.4 & - & 0.5 \\
\hline Glycerin $^{1}$ & - & - & 0.2 \\
\hline Corn & - & - & 2.3 \\
\hline Urea $^{2}$ & - & - & 0.03 \\
\hline Feed-fat ${ }^{2}$ & 1.7 & - & 0.4 \\
\hline Soy pellet ${ }^{3}$ & - & - & 1.7 \\
\hline Rape expellers ${ }^{3}$ & - & - & 1.2 \\
\hline Cattle salt ${ }^{4}$ & 0.03 & 0.03 & 0.03 \\
\hline Rumen-protected protein ${ }^{1}$ & - & - & 1.9 \\
\hline Propylene-glycol ${ }^{1}$ & 0.2 & - & 0.2 \\
\hline Sugar beet chips & 0.32 & - & - \\
\hline Flavorful acid salt ${ }^{4}$ & 0.5 & - & - \\
\hline $\begin{array}{l}{ }^{1} \text { Dr. Pieper Technologie } \\
\text { Germany. } \\
{ }^{2} \text { Spezialfutter Neuruppin, } \\
{ }^{3} \text { Hauptgenossenschaft Nor } \\
{ }^{4} \text { Blattin Mineralfutterwerk }\end{array}$ & $\begin{array}{l}\text { Produktentw } \\
\text { Neuruppin, Ge } \\
\text { AG, Kiel, Ge }\end{array}$ & $\begin{array}{l}\text { icklung } \mathrm{GmbH} \\
\text { ermany. } \\
\text { ermany. }\end{array}$ & Wuthenow, \\
\hline
\end{tabular}

of metritis or endometritis in accordance with Sheldon et al. (2008). After each examination, a blood sample was obtained from a coccygeal vessel directly into tubes with EDTA and without any anticoagulants to acquire serum (Sarstedt, Nümbrecht, Germany). The EDTA containing the samples was kept on ice, whereas the serum samples were kept until clotting at $\sim 20^{\circ} \mathrm{C}$. After centrifugation $\left(2,000 \times g, 15 \mathrm{~min}, 4^{\circ} \mathrm{C}\right.$; Hettich EBA 20, Boston, MA), which occurred within $2 \mathrm{~h}$ after sampling, the samples were kept at $-20^{\circ} \mathrm{C}$ until further analyses. Moreover, if a decrease in the milk yield or feed intake of the cows was detected by the farm stuff, the farm veterinarian conducted a clinical examination and recorded the diagnosis according to the stated definitions provided herein. The day of AI and the

Table 2. Chemical composition of the TMR fed with regard to the different lactation periods

\begin{tabular}{|c|c|c|c|}
\hline \multirow[b]{2}{*}{ Item } & \multicolumn{2}{|c|}{ Dry-off ration } & \multirow{2}{*}{$\begin{array}{c}\begin{array}{c}\text { Fresh cow } \\
\text { ration }\end{array} \\
>\mathrm{d} 1 \\
\text { postpartum }\end{array}$} \\
\hline & $\begin{array}{c}\text { wk 6-2 } \\
\text { antepartum }\end{array}$ & $\begin{array}{c}\text { wk } 2-0 \\
\text { antepartum }\end{array}$ & \\
\hline $\mathrm{NE}_{\mathrm{L}}(\mathrm{MJ} / \mathrm{kg}$ of $\mathrm{DM})$ & 5.53 & 6.39 & 7.54 \\
\hline Crude ash (g/kg of DM) & 93 & 63 & 53 \\
\hline Crude fat $(\mathrm{g} / \mathrm{kg}$ of $\mathrm{DM})$ & 36 & 29 & 52 \\
\hline $\mathrm{CP}(\mathrm{g} / \mathrm{kg}$ of $\mathrm{DM})$ & 134 & 142 & 170 \\
\hline Crude fiber $(\mathrm{g} / \mathrm{kg}$ of $\mathrm{DM})$ & 267 & 193 & 157 \\
\hline
\end{tabular}


calving date were recorded using the farm management software (HERDE2, dsp-agrosoft, Paretz, Germany). A variety of pp diseases were identified, and the cows were defined as ill if such an illness was recorded once. Metabolic diseases, such as ketosis, were diagnosed if reductions in feed intake or milk yield occurred and if the urine tested positive for ketone bodies (Ketostix strip, Bayer, Leverkusen, Germany). Displacement of the abomasum was defined when reductions in feed intake or milk yield were observed and abdominal percussion and auscultation were positive. Cows with the following symptoms were suspected of having hypocalcemia: precarious motion, cold body surface, ataxia, and downer cow syndrome. Hypocalcemia was diagnosed if those symptoms disappeared after 1 infusion of $10 \mathrm{~g}$ of calcium as $25 \%$ calcium borogluconate. Fatty liver syndrome was suspected if the cows had a $\mathrm{BW}>800 \mathrm{~kg}$ at the time of calving and if the cows had reduced feed intake or displacement of the abomasum. Then, a liver biopsy was conducted and a flotation test was performed. If the biopsy floated in $1,020 \mathrm{mg} / \mathrm{mL}$ of $\mathrm{CuSO}_{4}$ (26\% fat in the liver), fatty liver syndrome was defined (Herdt et al., 1983). A mastitis was diagnosed when the milk showed compositional changes, the udder had signs of inflammation, and the veterinarian detected an elevated cell count in the milk using the California Mastitis Test (WDT, Garbsen, Germany) according to Sargeant et al. (2001; >100,000 cells/mL). The retention of fetal membranes (RFM) was defined if fetal membranes were still evident $12 \mathrm{~h}$ after calving. Uterine content and vaginal discharge before or after 21 $\mathrm{d}$ of calving indicated metritis or endometritis (Sheldon et al., 2008), which were combined as metritis for the statistical analyses.

\section{Endocrine Analyses}

IGF1. The total plasma IGF1 concentrations were determined using a commercial IGF1-ELISA kit (Active IGF1 ELISA; Beckman Coulter, CA) with standard operations according to the manual. The optical density was measured $(450 \mathrm{~nm})$, and the concentrations were calculated with Magellan software using the cubic spline modus (Magellan 3.11, Dortmund, Germany). The range of measurements was 10 to $450 \mathrm{ng} / \mathrm{mL}$. The analytical sensitivity was $0.03 \mathrm{ng} / \mathrm{mL}$. The intra- and interassay CV were 3.5 and $8.5 \%$, respectively.

Quantitative Western Blotting for IGFBP2 and IGFBP3. To analyze the concentrations of serum IGFBP2 and IGFBP3 via the binding capacities, a quantitative Western ligand blotting analysis of the serum was performed as previously described (Metzger et al., 2011). Briefly, before electrophoresis on a $5 \%$ stacking and $12 \%$ separating SDS-polyacrylamide gel, the serum samples were diluted 1:3 with phosphate buffer ( $\mathrm{pH} 7.4$ ), diluted again 1:2 with sample buffer [62.5 mM Tris-HCl (pH 6.8), 2\% (wt/vol) SDS, and $10 \%$ (wt/vol) sucrose], and boiled (5 min). The separated proteins were transferred to a polyvinyl fluoride membrane (Millipore, Schwalbach, Germany). The blots were blocked using 1\% fish gelatin and incubated with $\left[{ }^{125} \mathrm{I}\right]$ IGF1. Using recombinant human IGFBP2 and IGFBP3 as internal standards on each blot, the IGFBP were quantified on a Phosphor-Imager Storm (Molecular Dynamics, Sunnyvale, CA). The intra-assay variances for the IGFBP2 and IGFBP3 determinations in bovine serum were less than $10 \%$. The interassay variances ranged between 15 and $20 \%$, which is acceptable for Western blot-based technologies. The lower limits of quantification in the bovine serum were $0.2 \mathrm{ng}$ for IGFBP2 and $1.1 \mathrm{ng}$ for IGFBP3.

NEFA. The serum concentrations of NEFA were measured using a photometric automatic clinical chemistry analyzer (ABX Pentra 400, Horiba, Montpellier, France) by using the NEFA-HR2 Olympus AU 400 Kit (mti-diagnostics GmbH, Idstein, Germany). The intraassay CV was $6.2 \%$.

\section{Statistics}

The statistical evaluation of the blood data was performed using SPSS (Version 17.0., SPSS Inc., Chicago, IL). All the data (IGF1, IGFBP2 and IGFBP3, and NEFA) were tested for normal distributions using the Kolmogorov-Smirnov test, as modified by Lilliefors (1967), and by a visual inspection of the histograms. The BCS and IGF1 concentrations were tested for differences between the 3 sampling periods using Student's $t$-test. Health status was tested for significant differences using Fisher's exact test or a chi-squared test. A relative risk assessment was performed to evaluate the potential uses of IGF1, IGFBP2, and NEFA as risk markers for pp diseases. A logistic regression model was developed (odds ratio), and a receiver operating characteristics (ROC) curve was constructed to determine the highest possible sensitivity and specificity. The Youden index was calculated using the following formula: sensitivity + specificity -1 . A $P$-value of $<0.05$ was considered significant, and a $P$-value between 0.05 and $\leq 0.10$ was classified as a statistical tendency.

\section{RESULTS}

\section{Diseases}

A total of 189 (50.1\%) cows developed production diseases pp, whereas 188 cows (49.9\%) remained healthy during the transition from late pregnancy to 
Table 3. Absolute and relative numbers of cows (percentage of diseased cows out of all tested cows; $\mathrm{n}=377$ ) with any production disease within the first 4 wk after calving ${ }^{1}$

\begin{tabular}{lcccccccc}
\hline Item & Ketosis & DLA & $\begin{array}{c}\text { Rumen } \\
\text { atony }\end{array}$ & Hypocalcemia & $\begin{array}{c}\text { Fatty } \\
\text { liver }\end{array}$ & Metritis & Mastitis & RFM \\
\hline Number & 30 & 20 & 14 & 12 & 5 & 66 & 34 \\
Percentage & 7.9 & 5.3 & 3.7 & 3.2 & 1.3 & 17.5 & 9.0 & 5.0 \\
\hline
\end{tabular}

${ }^{1} \mathrm{DLA}=$ displacement of the left abomasum, $\mathrm{RFM}=$ retained fetal membranes.

early lactation. Of the diseased cows, $73(34 \%)$ had metabolic diseases, and $142(66 \%)$ had diseases of the reproductive system (Table 3 ).

\section{BCS and Milk Yield}

The BCS of the cows was $4.3 \pm 0.03$ before calving and decreased pp $(3 \mathrm{wk}=3.2 \pm 0.03 ; 4 \mathrm{wk}=3.1$ $\pm 0.03 ; P<0.01)$. The mean BCS remained constant between 3 and 4 wk pp $(P=0.13)$. Calving occurred at $281 \pm 5 \mathrm{~d}$ after AI. The mean ap BCS of the healthy cows was comparable to the cows that developed any production disease after calving $(4.30 \pm 0.04$ vs. $4.22 \pm$ $0.05 ; P=0.21$ ). In the cows that developed fatty liver disease after calving $(\mathrm{n}=5)$, the ap BCS was higher $(4.90 \pm 0.10 ; P<0.01)$ compared with the healthy cows. The mean milk yield in the previous lactation of the healthy cows was comparable to that in the cows that developed any production disease after calving $(11,279.3 \pm 131.1$ vs. $11,145.3 \pm 145.2 \mathrm{~kg} ; P=0.49)$. No significant association between the previous milk yield and the occurrence of any pp production disease was found.

\section{IGF1}

In total, the IGF1 concentrations of all the cows ap were higher $(88.6 \pm 1.5 \mathrm{ng} / \mathrm{mL} ; P<0.01)$ compared with $3(50.4 \pm 1.4 \mathrm{ng} / \mathrm{mL})$ and $4 \mathrm{wk} p p(53.5 \pm 1.3 \mathrm{ng} /$ $\mathrm{mL})$. The cows with a greater loss in BCS between ap and 3 wk pp (BCS loss $>1, \mathrm{n}=213$ ) compared with the cows with a smaller BCS loss (BCS loss $\leq 1, \mathrm{n}=$ 164) showed similar IGF1 concentrations before calving $(90.2 \pm 4.8$ vs. $91.5 \pm 4.0 \mathrm{ng} / \mathrm{mL}$, respectively, $P=$ $0.68)$, but had lower IGF1 concentrations at $3(44.9 \pm$ 1.8 vs. $55.7 \pm 2.1 \mathrm{ng} / \mathrm{mL}$, respectively, $P<0.01)$ and 4 wk $(48.1 \pm 3.5$ vs. $57.4 \pm 3.6 \mathrm{ng} / \mathrm{mL}$, respectively, $P<$ $0.01)$ after parturition.

IGF1 as a Predictive Marker for Postpartum Ketosis. The cows that remained healthy after parturition had higher IGF1 concentrations ap (91.5 \pm $1.9 \mathrm{ng} / \mathrm{mL}$ ) compared with the cows that developed production diseases (ap $85.7 \pm 2.2 \mathrm{ng} / \mathrm{mL} ; P=0.05$ ). However, after parturition, the healthy cows had similar IGF1 levels $(3$ wk pp $=51.0 \pm 1.9 \mathrm{ng} / \mathrm{mL} ; 4$ wk pp $=53.9 \pm 1.8 \mathrm{ng} / \mathrm{mL}$ ) compared with the cows that developed production diseases $(3 \mathrm{wk} \mathrm{pp}=49.7$ $\pm 2.2 \mathrm{ng} / \mathrm{mL} ; 4$ wk pp $=52.9 \pm 1.9 \mathrm{ng} / \mathrm{mL} ; P=$ 0.64 and $P=0.70$ ). The cows with pp clinical ketosis had lower IGF1 concentrations ap than the cows that remained healthy after parturition $(P<0.01)$. The IGF1 concentrations of the cows with other diseases were comparable to the concentrations in the healthy cows (Figure 1, $P>0.05$ ). The ROC analysis revealed a significant association between IGF1 and ketosis $(P$ $<0.01$ ), the sensitivity of the ap IGF1 concentration as a marker for pp ketosis was 0.87 , the specificity was 0.43 , the positive predictive value (PPV) was 0.91 , and the negative predictive value (NPV) was 0.35 . The threshold for distinguishing healthy cows from cows with clinical ketosis was $61.7 \mathrm{ng} / \mathrm{mL}$ (Youden index $=0.31)$. The maximal Youden index was 0.45 and was found at a cutoff of $90.2 \mathrm{ng} / \mathrm{mL}$; with a sensitivity of 0.51 , a specificity of 0.83 , a PPV of 0.95 , and an NPV of 0.21 , the area under the curve (AUC) was 0.7305 (Figure 2). The cows with $10 \mathrm{ng} / \mathrm{mL}$ or higher ap IGF1 concentrations had a $37 \%$ reduced risk for developing clinical ketosis within the first 4 wk after parturition $($ odds ratio $=0.97)$.

\section{IGFBP}

The cows with ketosis and RFM had significantly lower IGFBP2 concentrations compared with the healthy cows (Figure 3; $P<0.01$ ). The ROC analysis revealed a significant association between IGFBP2 and ketosis $(P=0.01)$, a maximal Youden index of 0.37 at a cutoff of IGFBP2 $=3.5 \mathrm{ng} / \mu \mathrm{L}$ with a sensitivity of 0.70 and a specificity of 0.67 . The PPV was 0.93 and the NPV was 0.22 , corresponding to an AUC of 0.6625 . The IGFBP3 concentrations ap were comparable between the healthy cows and the cows that developed any production disease (Figure 4).

\section{NEFA}

The NEFA concentrations before calving were comparable between the healthy cows and the cows that developed a production disease pp (Figure $5 ; P>0.05$ ). The ROC analyses revealed no significant association 


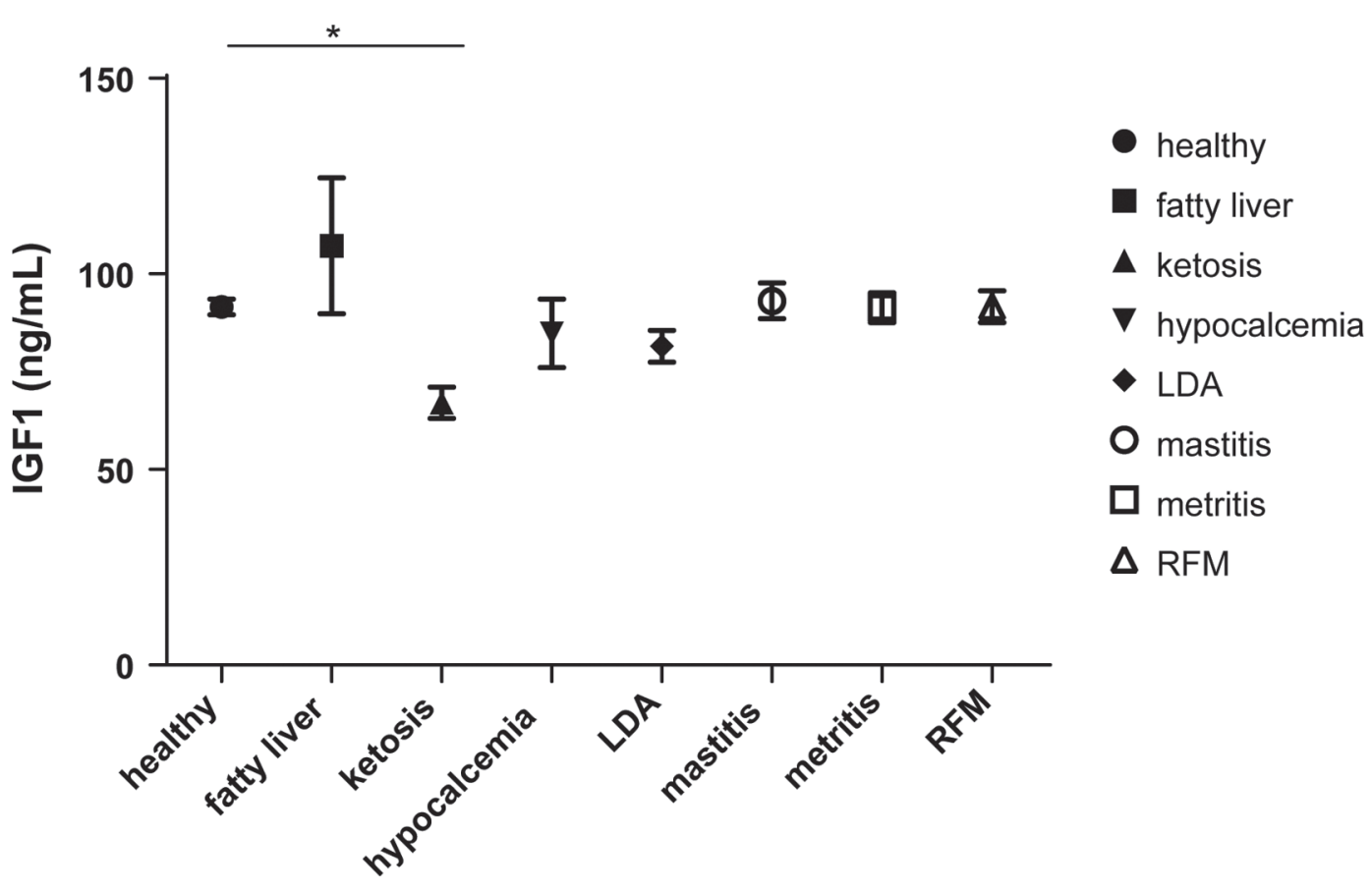

Figure 1. Antepartal (262-270 d after AI) IGF1 concentrations (mean \pm SD) of the healthy cows and the cows that developed any postpartal production disease $(28 \mathrm{~d}$ after calving). An asterisk $(*)$ indicates significant differences $(P<0.05)$ between the healthy cows and the cows with any production disease. $\mathrm{LDA}=$ left displaced abomasum; RFM $=$ retained fetal membranes.

between ap NEFA and pp clinical ketosis $(P=0.07)$, a maximal Youden index of 0.17 at a cutoff of $158 \mu \mathrm{mol} / \mathrm{L}$ of NEFA with a sensitivity of 0.80 and a specificity of 0.37 . The PPV was 0.88 and the NPV was 0.22 , corresponding to an AUC of 0.5832 .

\section{DISCUSSION}

Our study aimed to determine whether IGF1 and IGFBP were ap risk biomarkers for pp diseases in dairy cows under field conditions. It is well known that the transition from late pregnancy to early lactation is a critical period, with the occurrence of many orchestrated and interacting endocrine adaptations. If these adaptations are inadequate, the dairy cow is susceptible to metabolic and infectious diseases after calving (Chagas et al., 2007; Lean et al., 2013; Roche et al., 2013; Williams, 2013). In a previous study, it appeared that hepatic-derived IGF1 might serve as a promising indicative marker for pp ketosis (Piechotta et al., 2012). In our study, IGF1 was significantly lower between 242 and $262 \mathrm{~d}$ after $\mathrm{AI}$ in cows that developed a production disease after calving. Detailed studies on the differences between cows selected for either low or high ap IGF1 levels have revealed that NEFA concentrations increased after the IGF1 concentration was already very low (Piechotta et al., 2013, 2014). Elevated GH in catabolic conditions also has lipolytic potential combined with catecholamines and low insulin levels, and thus may be related to increased NEFA values (Houseknecht and Bauman, 1997; Lanna and Bauman, 1999; Rose et al., 2009). Furthermore, decreased IGF1 concentrations increase the $\mathrm{GH}$ release because of a reduced negative feedback at the pituitary level (Hannon et al., 1991; Kobayashi et al., 1999; Lucy et al., 2001). Because of this regulation, IGF1 may be more effective as a very early risk indicator for pp ketosis compared with NEFA or BHBA concentrations. The IGF1 concentrations in the present study were significantly lower in the cows that developed clinical pp ketosis compared with the healthy cows or the cows with other production diseases. Additionally, the NEFA concentrations were not significantly different at this early period of sampling (d 262-270 after AI); however, the standard deviation of the NEFA concentrations was higher in this group than in the other groups. This result may indicate that the initiation of lipolysis and the increased NEFA values were a result of lower IGF1 levels; therefore, IGF1 serum levels may be useful for the identification of cows at risk for ketosis as early as possible. A low BCS after calving was associated with a higher risk for ketosis during early lactation (Koeck et al., 2014). In the present study, the ap BCS was comparable between the healthy cows and the cows that developed ketosis. Notably, the BCS of the cows in the present study was high, which could be a confounding variable. 


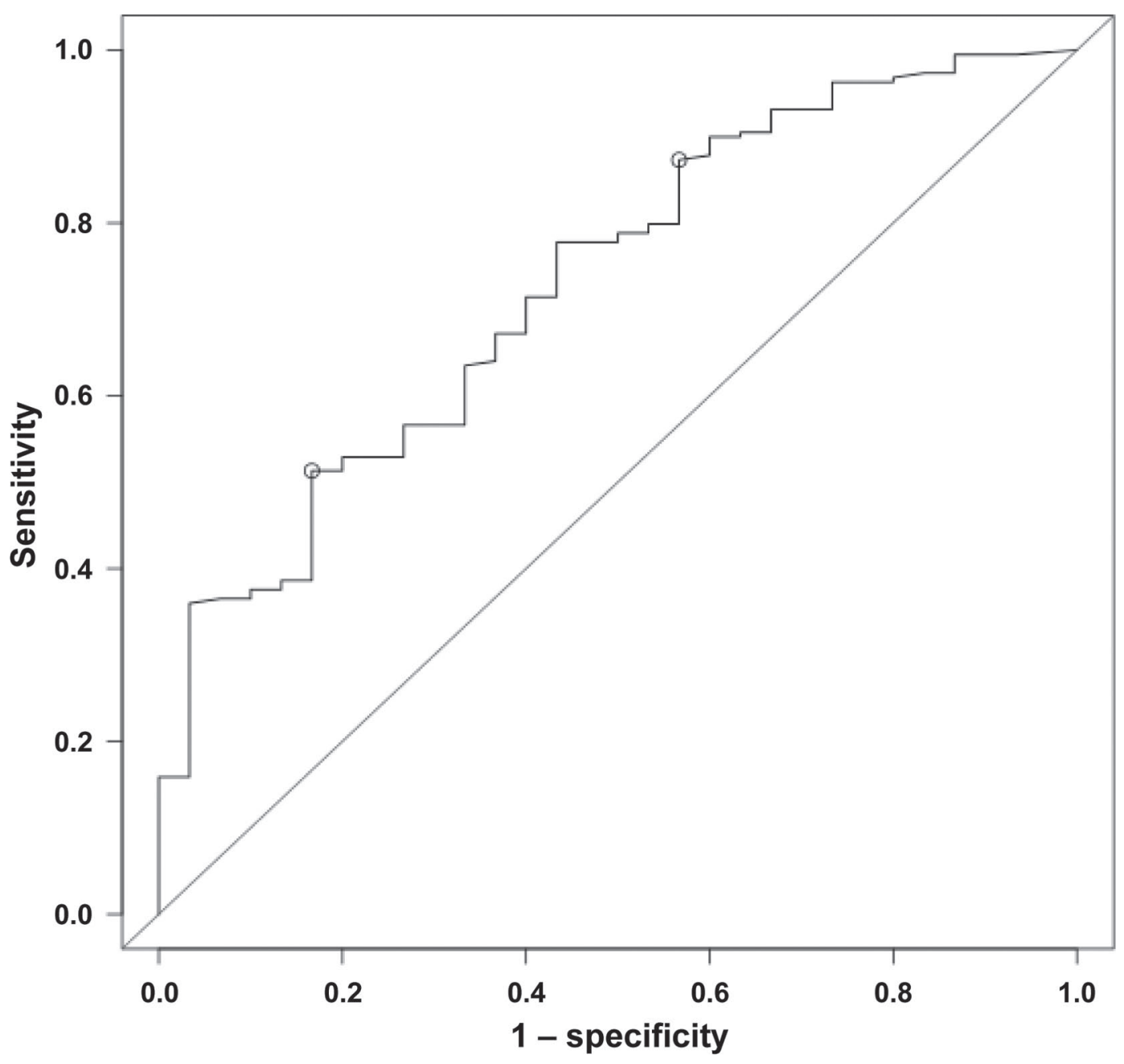

Figure 2. Receiver operating characteristic curve for the IGF1 concentrations in the cows with postpartum ketosis. The 2 circles indicate the following thresholds: IGF1at $90.2 \mathrm{ng} / \mathrm{mL}$ with sensitivity of 0.51 , specificity of 0.83 , positive predictive value (PPV) of 0.95 , and negative predictive value (NPV) of 0.21 ; and IGF1at $61.7 \mathrm{ng} / \mathrm{mL}$ with sensitivity of 0.87 , specificity of 0.43 , PPV of 0.91 , and NPV of 0.35 .

The measured IGF1 was defined as the total IGF1, which included all IGF1 molecules free or bound to their IGFBP. In the circulation, the main binding protein is IGFBP3, which complexes IGF1 with the acid labile subunit and primarily increases the half-life (Rajaram et al., 1997; Nedbal et al., 2000). Notably, the IGFBP3 concentration did not correlate with total IGF1 and was comparable between the healthy cows and the cows with pp diseases. It must be noted that the IGFBP were determined using a Western blot with a high intra-assay $\mathrm{CV}$, which might be responsible for this not significant correlation. Piechotta et al. (2013) found that IGFBP3 concentrations decreased toward calving and that cows with low IGF1 concentrations did not have significantly lower IGFBP3 serum concentrations in late pregnancy. Feed restrictions can cause lower IGF1 and IGFBP3 concentrations pp, as was demonstrated by Gross et al. (2011), but in other studies no significant differences between IGF1 and IGFBP3 concentrations with respect to feed restrictions were detected (Laeger et al., 2014). With this respect, factors other than feed intake may regulate hepatic IGF1 production and IGFBP3 concentrations in the blood. One possibility for the absence of a correlation between total IGF1 and IGFBP3 could be that proteases caused a cleavage of IGFBP3 in late pregnancy, as has been described in rats (Fowlkes et al., 1994; Wu et al., 1999). Even if human recombinant standards were used for the quantification of bovine IGFBP, a methoddependent reason for the difference between IGF1 and IGFBP3 concentrations is not obvious. This assumption is supported by the high sequence homologies present in the terminal protein domains from IGFBP of different vertebrate species. Piechotta et al. (2013) published RIA data for IGFBP2 in serum from cattle using a validated assay and obtained concentrations 


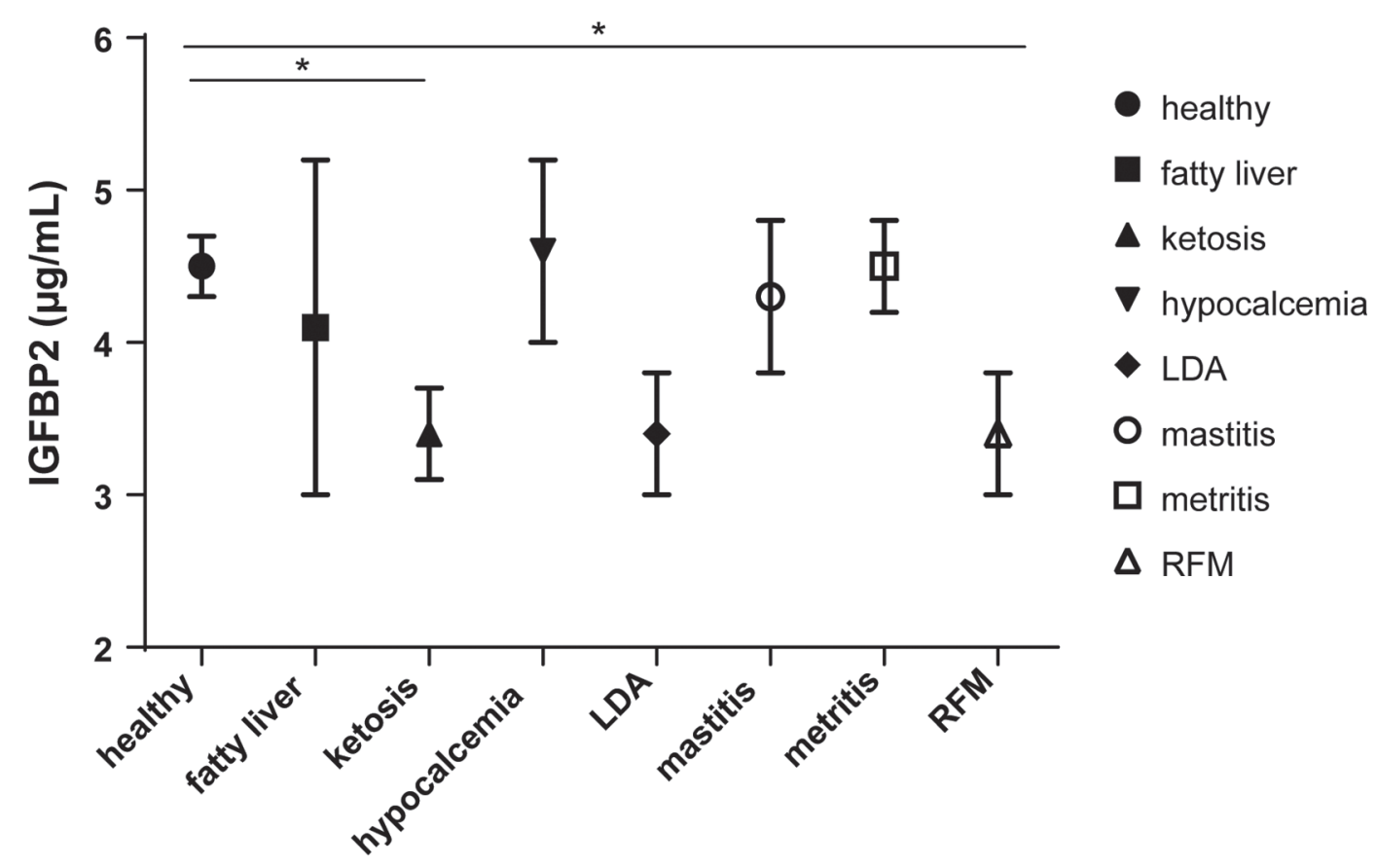

Figure 3. Antepartal (262-270 d after AI) insulin-like growth factor binding protein 2 (IGFBP2) concentrations of the healthy cows and the cows that developed a postpartal production disease $\left(28 \mathrm{~d}\right.$ after calving). An asterisk $\left(^{*}\right)$ indicates significant differences with regard to the healthy cows $(P<0.05)$. LDA $=$ left displaced abomasum; RFM $=$ retained fetal membranes.

ranging between 0.5 to $2.5 \mu \mathrm{g} / \mathrm{mL}$; these findings were consistent with Cohick et al. (1992) and Renaville et al. (2000). The IGFBP3 values that were obtained by the Western blot technique were also comparable to pub- lished data generated by an ELISA specific for bovine IGFBP3 that ranged between 1 and $3 \mu \mathrm{g} / \mathrm{mL}$ (Hennies and Sauerwein, 2003). This comparison shows that the values were similar even when measured by different

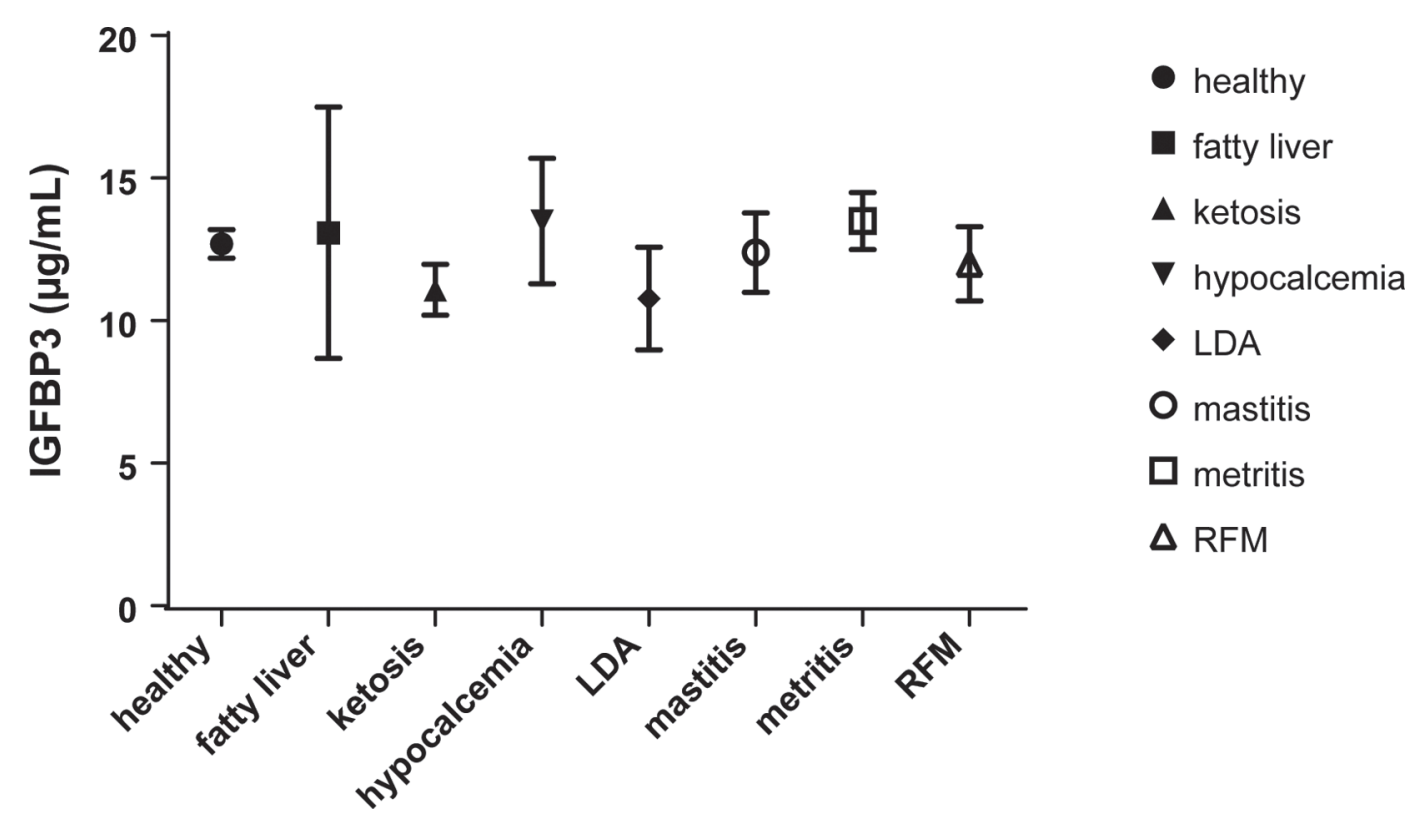

Figure 4. Antepartal (262-270 d after AI) insulin-like growth factor binding protein 3 (IGFBP3) concentrations of the healthy cows and the cows that developed a postpartal production disease $\left(28 \mathrm{~d}\right.$ after calving). An asterisk $\left.{ }^{*}\right)$ indicates significant differences $(P<0.05)$ between the healthy cows and the cows with any production disease. LDA = left displaced abomasum; RFM = retained fetal membranes. 


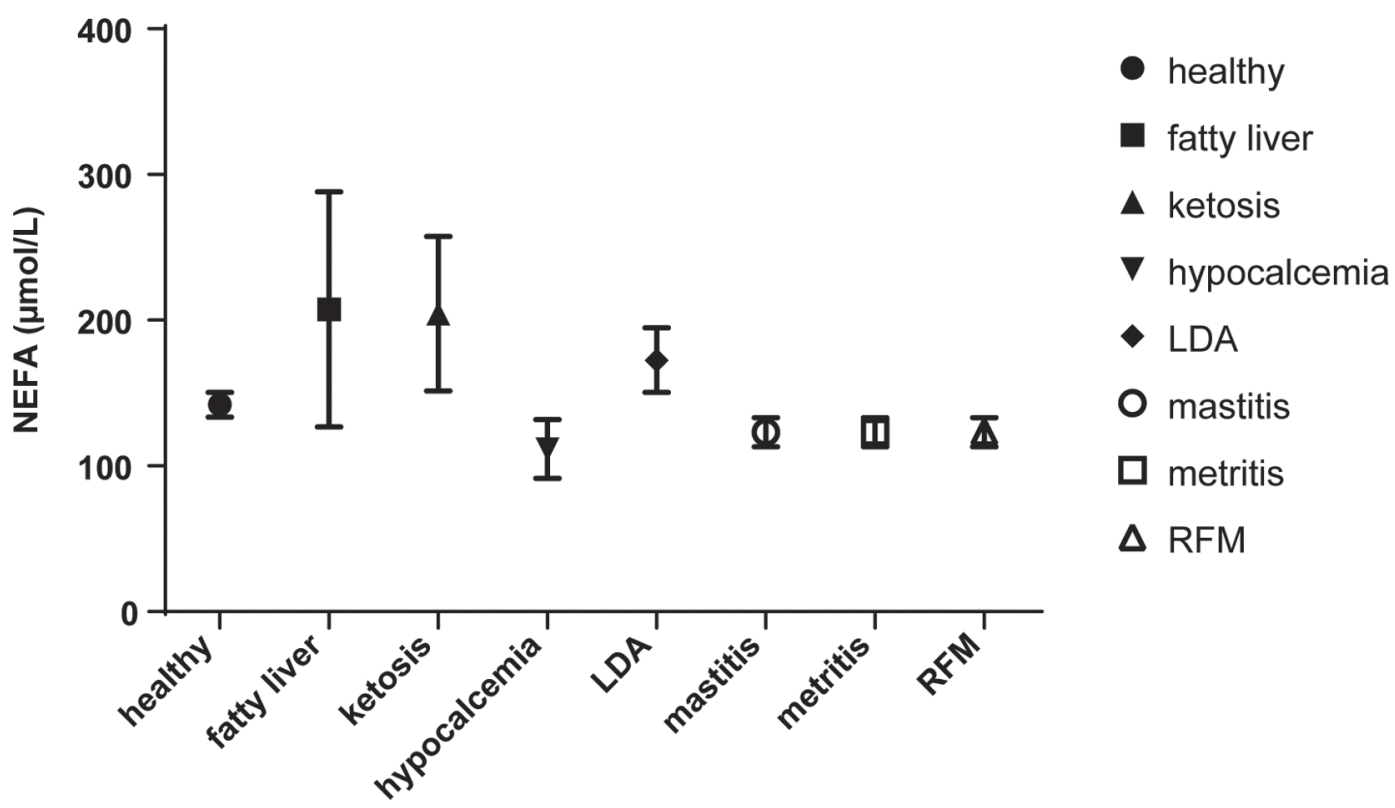

Figure 5. Antepartal (262-270 d after AI) NEFA concentrations of the healthy cows and the cows that developed a postpartal production disease (28 d after calving). An asterisk $(*)$ indicates significant differences with regard to the healthy cows $(P<0.05)$. LDA $=$ left displaced abomasum; RFM = retained fetal membranes.

techniques. This result may additionally underpin the validity of the method used.

Notably, in cows with fatty liver disease, the standard deviations of the IGF1, IGFBP3, and NEFA concentrations were high, which may indicate a difference in the severity of hepatic fat accumulation reflected by peripheral metabolites. A greater fat content in the liver has also previously been shown to be correlated with greater fat mobilization (Hammon et al., 2009), which may substantiate this speculation. A more detailed differentiation of the fatty liver syndrome would have been of interest, but that was not addressed in the present study.

For a screening test of pp ketosis, a high sensitivity is required. The ROC analyses revealed a threshold of 62 $\mathrm{ng} / \mathrm{mL}$ for IGF1 with a sensitivity of 0.87 , a specificity of 0.43 , and a maximal Youden index of 0.31 (cutoff $=$ $90 \mathrm{ng} / \mathrm{mL}$; sensitivity of 0.51 and specificity of 0.83 ). Therefore, depending on the threshold used, either a higher sensitivity or specificity can be chosen for a potential screening test. However, differences among assays and laboratories suggest that IGF1 concentrations in the blood must be evaluated for a specific laboratory and test method. The assay results for the IGF1 tests indicating a sensitivity of 0.51 , a specificity of 0.83 , and a Youden index of 0.31 appear to be superior to those of NEFA in our study in predicting the risk of ketosis after calving, given the Youden index of 0.17 with a sensitivity of 0.80 and a specificity of 0.37 . It is notable that whereas IGF1 was less sensitive, it was more specific, and had a higher total Youden index and a higher AUC than the NEFA values. Although ap NEFA and pp BHBA concentrations were both associated with the development of clinical disease, pp serum NEFA concentrations were the most associated with the risk of developing clinical ketosis (Lean et al., 1994; Ospina et al., 2010). However, a closer look at sensitivity and specificity clearly showed that the IGF1 concentrations determined in the present study had a higher specificity and sensitivity than did the NEFA concentrations and could be measured earlier before calving. A NEFA concentration measured $14 \mathrm{~d}$ before calving had a sensitivity of 0.53 and a specificity of 0.61 for pp clinical ketosis, whereas BHBA had a sensitivity of 0.57 and a specificity of 0.8 after calving (Ospina et al., 2010). In a study by Chapinal et al. (2011), NEFA concentrations obtained 1 wk before calving were associated with an increased risk of RFM, metritis, and left displaced abomasum, but not with clinical ketosis (Chapinal et al., 2011). In other studies, the NEFA concentrations $10 \mathrm{~d}$ before calving indicated a risk for displaced abomasum and BHBA (subclinical ketosis), and in the week after parturition, they indicated a risk for clinical ketosis (LeBlanc, 2010). An extensive evaluation of 3 different BHBA-measuring methods in either milk or urine revealed a high specificity (0.97 and 0.99) for diagnosing ketosis, whereas the sensitivity for the diagnosis was lower (0.55-0.98). These data also demonstrate that a sensitivity of 0.9 and a specificity of 0.4 are adequate for predicting ketosis in healthy 
ap cows weeks before clinical symptoms occur. Overall, the data of the present study clearly indicate that IGF1 and IGFBP2 are more accurate and serve as earlier risk indicators for ketosis in cows. Early measurement can lead to appropriate management conditions or feeding additives to assist cows during the transition from late pregnancy to early lactation and to prevent ketosis.

Notably, the ap IGFBP2 concentrations were lower in the cows with pp clinical ketosis and RFM; again, a high standard deviation in the fatty liver group was obvious. In contrast to the decrease in IGF1 and IGFBP3, the blood concentrations of IGFBP2, the second most abundant binding protein, increased after parturition (Vicini et al., 1991; Fenwick et al., 2008; Piechotta et al., 2013). The IGFBP2 level was shown to be affected by feed restrictions 3 wk after parturition in dairy cows (Gross et al., 2011), but not during midlactation (Laeger et al., 2014), which indicated that different regulations were operating as calving approached. In a previous study, hepatic IGFBP2 mRNA expression pp was positively correlated with NEFA and BHBA and negatively correlated with hepatic glycogen, blood glucose, and IGF1 (Fenwick et al., 2008). However, there appeared to be an early ap signal for IGFBP2 production. In humans, IGFBP2 was shown to affect insulin resistance and played a role in metabolic homeostasis (Wheatcroft and Kearney, 2009; Ruan and Lai, 2010). It is well known that IGFBP2 is suppressed by GH (Hoeflich et al., 2014); thus, lower IGFBP2 serum levels found in ketosis may be indicative of the increased $\mathrm{GH}$ secretion discussed earlier, which nicely supports our hypothesis. However, the specific functions of this binding protein regarding metabolic adaptations have not yet been elucidated in cattle. Our data support that monitoring IGFBP, particularly IGFBP2, might reflect the GH status or even be useful as early biomarkers of distinct health conditions or abnormalities. Supposedly a key metabolic signaling molecule that interacts between metabolism and fertility (Wathes, 2012), this binding protein was indicative of RFM in the present study. Because it has also been shown that cows with higher genetic fertility had a higher hepatic expression of IGFBP2 (Cummins et al., 2012), further studies on the factors affecting this binding protein appear to be promising.

\section{CONCLUSIONS}

In conclusion, IGF1 and IGFBP2 levels measured ap between 262 and $270 \mathrm{~d}$ after AI were indicative of pp clinical ketosis. Lower IGF1 production in the liver might lead to higher GH secretion, which can initiate lipolysis and result in increasing NEFA concentrations, which may increase the risk of ketosis. Therefore, com- pared with NEFA or BHBA, IGF1 and IGFBP2 may represent earlier biomarkers of inadequate metabolic adaptation to the high energy demands required pp. To use IGF1 concentrations in the blood as a diagnostic test, the threshold must be evaluated for a specific laboratory and test method.

\section{ACKNOWLEDGMENTS}

We thank Martina Baumgarten and Angela Jordan (University of Veterinary Medicine, Clinic for Cattle, Endocrinology, Hanover, Germany) for their technical support with the hormone analyses and Andreas Heinrich (Agrargenossenschaft Uckermark Agrar, Göritz, Germany) for the kind consent to perform this study on the dairy farm.

\section{REFERENCES}

Chagas, L. M., J. J. Bass, D. Blache, C. R. Burke, J. K. Kay, D. R Lindsay, M. C. Lucy, G. B. Martin, S. Meier, F. M. Rhodes, J. R. Roche, W. W. Thatcher, and R. Webb. 2007. Invited review: New perspectives on the roles of nutrition and metabolic priorities in the subfertility of high-producing dairy cows. J. Dairy Sci. 90:4022-4032.

Chapinal, N., M. Carson, T. F. Duffield, M. Capel, S. Godden, M. Overton, J. E. P. Santos, and S. J. LeBlanc. 2011. The association of serum metabolites with clinical disease during the transition period. J. Dairy Sci. 94:4897-4903.

Cohick, W. S., M. A. McGuire, D. R. Clemmons, and D. E. Bauman. 1992. Regulation of insulin-like growth factor-binding proteins in serum and lymph of lactating cows by somatotropin. Endocrinology 130:1508-1514.

Cummins, S. B., S. M. Waters, A. C. O. Evans, P. Lonergan, and S. T. Butler. 2012. Genetic merit for fertility traits in Holstein cows: III Hepatic expression of somatotropic axis genes during pregnancy and lactation. J. Dairy Sci. 95:3711-3721.

Edmonson, A. J., I. J. Lean, L. D. Weaver, T. Farver, and G. Webster. 1989. A body condition scoring chart for Holstein dairy cows. J. Dairy Sci. 72:68-78.

Fenwick, M. A., R. Fitzpatrick, D. A. Kenny, M. G. Diskin, J. Patton, J. J. Murphy, and D. C. Wathes. 2008. Interrelationships between negative energy balance (NEB) and IGF regulation in liver of lactating dairy cows. Domest. Anim. Endocrinol. 34:31-44.

Fowlkes, J. L., K. Suzuki, H. Nagase, and K. M. Thrailkill. 1994. Proteolysis of insulin-like growth factor binding protein-3 during rat pregnancy: A role for matrix metalloproteinases. Endocrinology 135:2810-2813.

Gohary, K., S. J. LeBlanc, K. D. Lissemore, M. W. Overton, M. Von Massow, and T. F. Duffield. 2014. Effect of prepartum administration of recombinant bovine somatotropin on health and performance of lactating dairy cows. J. Dairy Sci. 97:6231-6241.

Gross, J., H. A. van Dorland, F. J. Schwarz, and R. M. Bruckmaier. 2011. Endocrine changes and liver mRNA abundance of somatotropic axis and insulin system constituents during negative energy balance at different stages of lactation in dairy cows. J. Dairy Sci. 94:3484-3494

Hammon, H. M., G. Stürmer, F. Schneider, A. Tuchscherer, H. Blum, T. Engelhard, A. Genzel, R. Staufenbiel, and W. Kanitz. 2009. Performance and metabolic and endocrine changes with emphasis on glucose metabolism in high-yielding dairy cows with high and low fat content in liver after calving. J. Dairy Sci. 92:1554-1566.

Hannon, K., A. Gronowski, and A. Trenkle. 1991. Relationship of liver and skeletal muscle IGF1 mRNA to plasma GH profile, production 
of IGF1 by liver, plasma IGF1 concentrations, and growth rates of cattle. Proc. Soc. Exp. Biol. Med. 196:155-163.

Hennies, M., and H. Sauerwein. 2003. Purification of bovine IGFBP3 and the development of an enzyme immunoassay for the protein. J. Immunol. Methods 281:9-15.

Herdt, T. H., J. S. Liesman, B. J. Gerloff, and R. S. Emery. 1983. Reduction of serum triacylglycerol-rich lipoprotein concentrations in cows with hepatic lipidosis. Am. J. Vet. Res. 44:293-296.

Hoeflich, A., E. Wirthgen, R. David, C. F. Classen, M. Spitschak, and J. Brenmoehl. 2014. Control of IGFBP2 expression by steroids and peptide hormones in vertebrates. Front. Endocrinol. (Lausanne) $5: 43$.

Houseknecht, K. L., and D. E. Bauman. 1997. Regulation of lipolysis by somatotropin: functional alteration of adrenergic and adenosine signaling in bovine adipose tissue. J. Endocrinol. 152:465-475.

Kawashima, C., S. Fukihara, M. Maeda, E. Kaneko, C. A. Montoya, M. Matsui, T. Shimizu, N. Matsunaga, K. Kida, Y. I. Miyake, D. Schams, and A. Miyamoto. 2007. Relationship between metabolic hormones and ovulation of dominant follicle during the first follicular wave post-partum in high-producing dairy cows. Reproduction 133:155-163.

Kobayashi, Y., C. K. Boyd, C. J. Bracken, W. R. Lamberson, D. H. Keisler, and M. C. Lucy. 1999. Reduced growth hormone receptor (GHR) messenger ribonucleic acid in liver of periparturient cattle is caused by a specific down-regulation of GHR 1A that is associated with decreased insulin-like growth factor I. Endocrinology 140:3947-3954.

Koeck, A., J. Jamrozik, F. S. Schenkel, R. K. Moore, D. M. Lefebvre, D. F. Kelton, and F. Miglior. 2014. Genetic analysis of milk $\beta$-hydroxybutyrate and its association with fat-to-protein ratio, body condition score, clinical ketosis, and displaced abomasum in early first lactation of Canadian Holsteins. J. Dairy Sci. 97:72867292 .

Laeger, T., E. Wirthgen, M. Piechotta, F. Metzger, C. C. Metges, B. Kuhla, and A. Hoeflich. 2014. Effects of parturition and feed restriction on concentrations and distribution of the insulin-like growth factor-binding proteins in plasma and cerebrospinal fluid of dairy cows. J. Dairy Sci. 97:2876-2885.

Lanna, D. P., and D. E. Bauman. 1999. Effect of somatotropin, insulin, and glucocorticoid on lipolysis in chronic cultures of adipose tissue from lactating cows. J. Dairy Sci. 82:60-68.

Lean, I. J., M. L. Bruss, H. F. Troutt, J. C. Galland, T. B. Farver, J. Rostami, C. A. Holmberg, and L. D. Weaver. 1994. Bovine ketosis and somatotrophin: Risk factors for ketosis and effects of ketosis on health and production. Res. Vet. Sci. 57:200-209.

Lean, I. J., R. Van Saun, and P. J. Degaris. 2013. Energy and protein nutrition management of transition dairy cows. Vet. Clin. North Am. Food Anim. Pract. 29:337-366.

LeBlanc, S. 2010. Monitoring metabolic health of dairy cattle in the transition period. J. Reprod. Dev. 56:S29-35.

Lilliefors, H. W. 1967. On the Kolmogorov-Smirnov test for normality with mean and variance unknown. J. Am. Stat. Assoc. 62:399 402.

Lucy, M. C., H. Jiang, and Y. Kobayashi. 2001. Changes in the somatotropic axis associated with the initiation of lactation. J. Dairy Sci. 84:113-119.

Metzger, F., W. Sajid, S. Saenger, C. Staudenmaier, C. van der Poel, B. Sobottka, A. Schuler, M. Sawitzky, R. Poirier, D. Tuerck, E. Schick, A. Schaubmar, F. Hesse, K. Amrein, H. Loetscher, G. S. Lynch, A. Hoeflich, P. De Meyts, and H. J. Schoenfeld. 2011. Separation of fast from slow anabolism by site-specific PEGylation of insulin-like growth factor I (IGF-I). J. Biol. Chem. 286:1950119510.

Nedbal, S., N. Zink, H. Lahm, A. Hoeflich, and E. Wolf. 2000. Functional dissection of the insulin-like growth factor (IGF) systemProspects for animal breeding. Arch. Tierzucht. Dummerstorf 43:223-230.

Ospina, P. A., D. V. Nydam, T. Stokol, and T. R. Overton. 2010. Evaluation of nonesterified fatty acids and beta-hydroxybutyrate in transition dairy cattle in the northeastern United States: Criti- cal thresholds for prediction of clinical diseases. J. Dairy Sci. 93:546-554.

Piechotta, M., L. Holzhausen, M. G. Araujo, M. Heppelmann, A. Sipka, C. Pfarrer, H.-J. Schuberth, and H. Bollwein. 2014. Antepartal insulin-like growth factor concentrations indicating differences in the metabolic adaptive capacity of dairy cows. J. Vet. Sci. 15:343-352

Piechotta, M., K. Kedves, M. G. Araujo, A. Hoeflich, F. Metzger, M. Heppelmann, A. Muscher-Banse, C. Wrenzycki, C. Pfarrer, H.J. Schuberth, M. Hoedemaker, H. Bollwein, and M. Kaske. 2013. Hepatic mRNA expression of acid labile subunit and deiodinase 1 differs between cows selected for high versus low concentrations of insulin-like growth factor 1 in late pregnancy. J. Dairy Sci. 96:3737-3749.

Piechotta, M., A. K. Sander, J. P. Kastelic, R. Wilde, M. Heppelmann, B. Rudolphi, H.-J. Schuberth, H. Bollwein, and M. Kaske. 2012. Short communication: Prepartum plasma insulin-like growth factor-I concentrations based on day of insemination are lower in cows developing postpartum diseases. J. Dairy Sci. 95:1367-1370.

Rajaram, S., D. J. Baylink, and S. Mohan. 1997. Insulin-like growth factor-binding proteins in serum and other biological fluids: Regulation and functions. Endocr. Rev. 18:801-831.

Renaville, R., C. Van Eenaeme, B. H. Breier, L. Vleurick, C. Bertozzi, N. Gengler, J. L. Hornick, I. Parmentier, L. Istasse, V. Haezebroeck, S. Massart, and D. Portetelle. 2000. Feed restriction in young bulls alters the onset of puberty in relationship with plasma insulin-like growth factor-I (IGF-I) and IGF-binding proteins. Domest. Anim. Endocrinol. 18:165-176.

Roche, J. R., J. K. Kay, N. C. Friggens, J. J. Loor, and D. P. Berry. 2013. Assessing and managing body condition score for the prevention of metabolic disease in dairy cows. Vet. Clin. North Am. Food Anim. Pract. 29:323-336.

Rose, M. T., T. E. C. Weekes, and P. Rowlinson. 2009. Relationship between the milk yield response to short-term bovine somatotropin treatment and the lipolytic response to adrenaline in dairy cows. Domest. Anim. Endocrinol. 36:24-31.

Ruan, W., and M. Lai. 2010. Insulin-like growth factor binding protein: A possible marker for the metabolic syndrome? Acta Diabetol. $47: 5-14$.

Sargeant, J. M., K. E. Leslie, J. E. Shirley, B. J. Pulkrabek, and G. H. Lim. 2001. Sensitivity and specificity of somatic cell count and California Mastitis Test for identifying intramammary infection in early lactation. J. Dairy Sci. 84:2018-2024.

Sheldon, I. M., E. J. Williams, A. N. A. Miller, D. M. Nash, and S. Herath. 2008. Uterine diseases in cattle after parturition. Vet. J. 176:115-121.

Vicini, J. L., F. C. Buonomo, J. J. Veenhuizen, M. A. Miller, D. R. Clemmons, and R. J. Collier. 1991. Nutrient balance and stage of lactation affect responses of insulin, insulin-like growth factor-I and factor-II, and insulin-like growth factor-binding protein-2 to somatotropin administration in dairy cows. J. Nutr. 121:16561664.

Wang, J., X. Zhu, C. Chen, X. Li, Y. Gao, P. Li, Y. Zhang, M. Long, Z. Wang, and G. Liu. 2012. Effect of insulin-like growth factor-1 (IGF1) on the gluconeogenesis in calf hepatocytes cultured in vitro. Mol. Cell. Biochem. 362:87-91.

Wathes, D. C. 2012. Mechanisms linking metabolic status and disease with reproductive outcome in the dairy cow. Reprod. Domest. Anim. 47:304-312.

Wheatcroft, S. B., and M. T. Kearney. 2009. IGF-dependent and IGFindependent actions of IGF-binding protein-1 and -2: Implications for metabolic homeostasis. Trends Endocrinol. Metab. 20:153162 .

Williams, E. J. 2013. Drivers of post-partum uterine disease in dairy cattle. Reprod. Domest. Anim. 48:53-58.

Wu, H. B., C. Y. Lee, and M. M. Rechler. 1999. Proteolysis of insulinlike growth factor binding protein-3 in serum from pregnant, nonpregnant and fetal rats by matrix metalloproteinases and serine proteases. Horm. Metab. Res. 31:186-191. 